\title{
Annual Waste Minimization Summary Report
}

\author{
Calendar Year 2010
}

U.S. Environmental Protection Agency
Identification No. NV3890090001

\author{
Prepared for \\ U.S. Department of Energy \\ National Nuclear Security Administration \\ Nevada Site Office

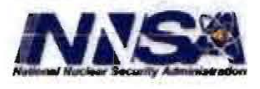

Prepared by

National Security Technologies, LLC

National Security Technologiesut

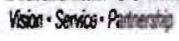

January 2011 


\section{DISCLAIMER}

Reference herein to any specific commercial product, process, or service by trade name, trademark, manufacturer, or otherwise, does not necessarily constitute or imply its endorsement, recommendation, or favoring by the United States Government or any agency thereof.

Available for sale to the public from:

U.S. Department of Commerce

National Technical Information Service

5301 Shawnee Road

Alexandria, VA 22312

Telephone: (800) 553-6847

Fax: (703) 605-6900

E-mail: orders@ntis.gov

Online ordering: http://www.ntis.gov/help/ordermethods.aspx

Available electronically at http://www.osti.gov/bridge

Available for a processing fee to the U.S. Department of Energy and its contractors, in paper, from:

U.S. Department of Energy

Office of Scientific and Technical Information

P.O. Box 62

Oak Ridge, TN 37831-0062

Telephone: (865) 576-8401

Fax: (865) 576-5728

E-mail: reports@adonis.osti.gov 


\section{TABLE OF CONTENTS}

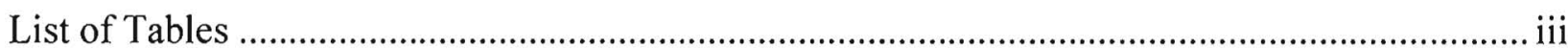

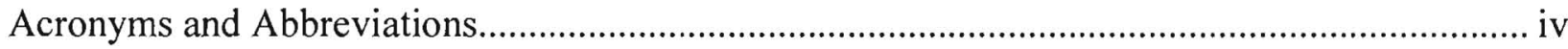

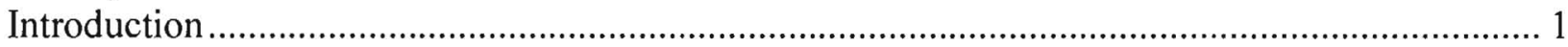

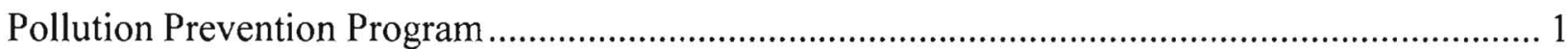

Major Pollution Prevention Accomplishments ......................................................................... 2

Comparison of Waste Generated in CY 2010 to Prior Years .................................................. 4

Comparison of Volume and Toxicity Reductions of Waste in CY 2010 to Prior Years ............... 6

\section{LIST OF TABLES}

Table 1. Radioactive Waste Generated ............................................................................... 5

Table 2. Hazardous Waste Generated .................................................................................. 5

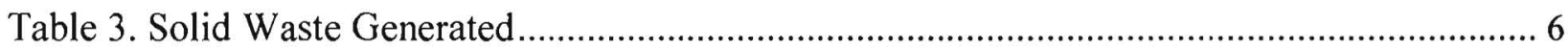

Table 4. Waste Reduced through P2 Activities .................................................................. 6

Table 5. CY 2010 Hazardous Waste Reductions ..................................................................... 7

Table 6. CY 2010 Solid Waste Reductions....................................................................... 8 


\section{ACRONYMS AND ABBREVIATIONS}

$\begin{array}{ll}\text { CY } & \text { calendar year } \\ \text { DOE } & \text { U.S. Department of Energy } \\ \text { EMS } & \text { Environmental Management System } \\ \text { EPA } & \text { Environmental Protection Agency } \\ \text { FY } & \text { fiscal year } \\ \text { JASPER } & \text { Joint Actinide Shock Physics Experimental Research } \\ \text { m }^{3} & \text { cubic meter } \\ \text { mton } & \text { metric ton } \\ \text { NDEP } & \text { Nevada Division of Environmental Protection } \\ \text { NNSA/NSO } & \text { National Nuclear Security Administration Nevada Site Office } \\ \text { NNSS } & \text { Nevada National Security Site } \\ \text { NSTec } & \text { National Security Technologies, LLC } \\ \text { P2 } & \text { Pollution Prevention } \\ \text { RCRA } & \text { Resource Conservation and Recovery Act } \\ \text { TRU } & \text { Transuranic } \\ \text { TSCA } & \text { Toxic Substance Control Act }\end{array}$




\section{Introduction}

This report summarizes the waste minimization efforts undertaken by National Security Technologies, LLC (NSTec), for the U. S. Department of Energy (DOE), National Nuclear Security Administration Nevada Site Office (NNSA/NSO), during calendar year (CY) 2010. This report was developed in accordance with the requirements of the Nevada National Security Site (NNSS) Resource Conservation and Recovery Act (RCRA) Permit (No. NEV HW0021), and as clarified in a letter dated April 21, 1995, from Paul Liebendorfer of the Nevada Division of Environmental Protection (NDEP) to Donald Elle of the U.S. Department of Energy, Nevada Operations Office.

The NNSA/NSO Pollution Prevention (P2) Program establishes a process to reduce the volume and toxicity of waste generated by NNSA/NSO activities and ensures that proposed methods of treatment, storage, and/or disposal of waste minimize potential threats to human health and the environment. The following information provides an overview of the P2 Program, major P2 accomplishments during the reporting year, a comparison of the current year waste generation to prior years, and a description of efforts undertaken during the year to reduce the volume and toxicity of waste generated by the NNSA/NSO.

\section{Pollution Prevention Program}

It is a priority of the NNSA/NSO to minimize the generation, release, and/or disposal of pollutants to the environment by implementing cost-effective $\mathrm{P} 2$ technologies, practices, and policies. A commitment to $\mathrm{P} 2$ minimizes the impact on the environment, improves the safety of operations, improves energy efficiency, and promotes the sustainable use of natural resources. To meet $\mathrm{P} 2$ goals identified each year, this commitment includes providing administrative support and financial resources. When economically feasible, source reduction is the preferred method of managing waste, followed by reuse/recycling, treatment, and landfill disposal as a last resort.

$\mathrm{NNSA} / \mathrm{NSO}$ requires contractors/laboratories to develop and maintain an Environmental Management System (EMS) per DOE Order 450.1A, "Environmental Protection Program." The EMS requires that contractors reduce or eliminate the generation of waste, the release of pollutants to the environment, and the use of Class I ozone-depleting substances. This requirement is achieved by means of source reduction, reuse, segregation and recycling, and procurement of recycled-content materials and environmentally preferable products and services. To minimize the generation of waste, project managers are required to incorporate waste minimization into the planning phase of their projects. Waste generating processes must be assessed to determine if the waste can be economically reduced or eliminated. Waste minimization activities determined to be cost effective are incorporated into the project plan, and adequate funding allocated to ensure their implementation.

For wastes in which source reduction is not feasible, an aggressive recycling program is maintained. Items recycled through the NNSA/NSO recycling program include paper, cardboard, aluminum cans, toner cartridges, inkjet cartridges, used oil, food waste from the cafeteria, tires, computers and software, scrap metal, rechargeable batteries, lead-acid batteries, and electric lamps (fluorescent, mercury vapor, metal halide, and high-pressure sodium). 
As required by Executive Order 13423, "Strengthening Federal Environmental, Energy, and Transportation Management," NNSA/NSO maintains an Environmentally Preferable Purchasing program where specific items designated by the U.S. Environmental Protection Agency (EPA) must contain a percentage of recycled materials. By following these guidelines when procuring supplies, the market for recycled content products is stimulated, resources saved, and the loop closed on recycling.

The NNSA/NSO P2 Program also includes an employee and public awareness program. Awareness of P2 issues is accomplished by means of disseminating articles using electronic mail, contractor and NNSA/NSO newsletters, maintenance of a P2 intranet web site, employee training courses, and participation at employee and community events. These activities are intended to increase awareness of P2 and environmental issues, and point out the importance of P2 for improving environmental conditions in the workplace and community.

\section{Major Pollution Prevention Accomplishments}

$>$ The Engine Maintenance, Assembly, and Disassembly Facility is being closed under the Federal Facility Agreement and Consent Order with the State of Nevada. Hazardous materials removal was performed in 2010. In an effort to support NNSA/NSO P2 objectives, reduce the volume, and minimize the disposal cost of materials generated and dispositioned as hazardous and regulated waste, the following waste streams were successfully recycled or reused:

* Mineral Oil - 11,000 gallons of mineral oil drained from forty leaded-glass shield windows and sent for recycle/reuse

* Diesel Fuel - 1,250 gallons of diesel fuel drained from locomotives and sent offsite for recycle/reuse

The CAT D-10N Caterpillar tractor/dozer, originally purchased in 1988, required a complete overhaul, including a new engine and exhaust. The old diesel engine and exhaust system was replaced with a remanufactured Tier 1 engine, and an Oxidation Catalyst added to the exhaust, which greatly reduces air emissions as mandated by the EPA's Clean Air Act.

In compliance with the Clean Air Act, Executive, and DOE Orders, the current emphasis is the reduction in greenhouse gases that lead to global warming including: Nitric Oxide and Nitrous Oxide (collectively NOx), Carbon Monoxide (CO), Carbon Dioxide (CO2), and Hydrocarbons (HC). A Tier 1 engine is designed to more efficiently burn the diesel fuel at a higher temperature to reduce the emissions of greenhouse gases and particulate matter. Some of the emissions are reduced even further by using an Oxidation Catalyst in the exhaust stream to reduce the $\mathrm{CO}$ and $\mathrm{HC}$ to $\mathrm{CO} 2$ and water, using the heat from the combustion process.

The rebuilt dozer uses ultra low sulfur biodiesel, which significantly reduces the amount of greenhouse gases emitted to the environment. The dozer now emits $22 \%$ less NOx and up to $39 \%$ less particulate matter. The old engine used approximately $16 \mathrm{gal} / \mathrm{hr}$ of diesel to operate. Preliminary data with the upgraded engine suggest that it takes approximately $11 \mathrm{gal} / \mathrm{hr}$ of B20 Biodiesel to operate, about $25 \%$ less fuel consumption. 
$>$ Through 2010, the NSO Energy Program has achieved the following in comparison with overall goals in DOE Orders:

- Scopes 1 and 2 Greenhouse gases (metric ton carbon dioxide equivalent [MT CO2e]) were reduced by $11 \%$ from the fiscal year (FY) 2008 baseline.

* Energy intensity (BTU/gsf) was reduced by 36.74\% from the FY 2003 baseline.

* Small onsite renewable energy sources were installed as practical and represented $0.5 \%$ of energy $(\mathrm{kWh})$ used at the NNSS.

* Alternative fuel usage (gals) increased by 153\% from the FY 2005 baseline.

* Petroleum consumption (gals) was reduced by $48 \%$ from the FY 2005 baseline.

* Meter installation was at $60.7 \%$ for all types (advanced electrical, natural gas, and water), with $16 \%$ of advanced meters installed.

* Cool roofs (gsf) installed as part of the Roof Asset Management Program (RAMP) represented $10 \%$ of buildings.

* Buildings compliant with the Five Guiding Principles were 5.6\% (gsf) or $4.4 \%$ (number of buildings).

* Production of potable and non-potable water was reduced by $17.3 \%$.

The NNSS received American Recovery and Reinvestment Act funds to demolish the Reactor Maintenance, Assembly, and Disassembly Facility (RMAD). The large volume of waste to be transported presented significant worker safety and environmental impacts. Steps were taken to minimize potential impacts by consolidating radioactive low-level waste (LLW) shipments for onsite disposal. This effort resulted in saving nearly 1,260 gallons of fuel and the corresponding air emissions.

A new Fire Station \#2 located at Area 6 of the NNSS was built and has been awarded LEED $^{\circledR}$ Gold established by the U.S. Green Building Council (USGBC) and verified by the Green Building Certification Institute (GBCI). LEED (Leadership in Energy and Environmental Design) is the nation's preeminent program for the design, construction, and operation of high-performance green buildings.

Fire Station \#2 achieved LEED certification for energy use, lighting, water and material use, as well as incorporating a variety of other sustainable strategies. By using less energy and water, LEED-certified buildings reduce greenhouse gas emissions, and contribute to a healthier environment. 
In 2010, the Nevada Site Office (NSO) and National Security Technologies (NSTec) completed the replacement of the 40+ year old car wash system at the NNSS in an effort to comply with the water conservation goals established in DOE Order 430.2B, "Departmental Energy, Renewable Energy and Transportation Management."

The previous car wash system lost 20 gallons of water per car wash and accommodated only $60 \%$ of the fleet. The new touchless car wash system loses only 7 gallons of water per car wash, and accommodates $90 \%$ of the current fleet, while recycling $85 \%$ of the 45 gallons of water used.

\section{Comparison of Waste Generated in CY 2010 to Prior Years}

Waste generation activities are presented in two source categories:

1. Routine Waste is waste generated from on-going operations (i.e., production, analytical, research and development laboratory operations, work for others, or any other periodic or recurring activity).

2. Cleanup Waste is waste generated from environmental restoration program activities, laboratory closeouts (i.e., discarding off-specification or out-of-date materials), spill cleanups, legacy wastes, wastes from decommissioning and demolition/transition operations, and all Toxic Substance Control Act (TSCA) wastes.

Table 1 compares radioactive waste generated onsite in CY 2010 with prior years. The volume of routine and cleanup waste generated is dependent upon the number and scope of projects funded during the year.

Since 2007, routine transuranic (TRU) waste has been generated by the Joint Actinide Shock Physics Experimental Research (JASPER) project and is stored in Area 5 until it will be shipped to the Waste Isolation Pilot Plant facility for disposal. Typically, DOE sites use waste disposal records as a means of tracking waste generation. However, since the JASPER waste has not yet been disposed, it is tracked and included with the quantities reported in Table 1. 
Table 1. Radioactive Waste Generated

\begin{tabular}{|c|c|c|c|}
\hline & Routine & Cleanup & Total \\
\hline CY 2010 & $1.1 \mathrm{~m}^{3^{*}}$ & $8,143.3 \mathrm{~m}^{3}$ & $8,144.4 \mathrm{~m}^{3}$ \\
\hline CY 2009 & $4.2 \mathrm{~m}^{3}$ & $1,684.7 \mathrm{~m}^{3}$ & $1,688.9 \mathrm{~m}^{3}$ \\
\hline CY 2008 & $251.6 \mathrm{~m}^{3}$ & $991.7 \mathrm{~m}^{3}$ & $1,243.3 \mathrm{~m}^{3}$ \\
\hline CY 2007 & $0.0 \mathrm{~m}^{3}$ & $1,940.7 \mathrm{~m}^{3}$ & $1,940.7 \mathrm{~m}^{3}$ \\
\hline CY 2006 & $0.0 \mathrm{~m}^{3}$ & $1,663.7 \mathrm{~m}^{3}$ & $1,663.7 \mathrm{~m}^{3}$ \\
\hline
\end{tabular}

${ }^{*} \mathrm{~m}^{3}=$ cubic meters

Table 2 compares the amount of hazardous waste generated in CY 2010 with the previous four years. Routine hazardous waste generation increased in CY 2010 due to demolition projects. The volume of cleanup waste generated is dependent upon the number and scope of cleanup projects funded during the year.

\section{Table 2. Hazardous Waste Generated}

\begin{tabular}{|c|c|c|c|}
\hline & Routine & Cleanup & Total \\
\hline CY 2010 & 9.8 mtons* $^{*}$ & 13.7 mtons & 23.5 mtons \\
\hline CY 2009 & 5.1 mtons & 2.4 mtons & 7.5 mtons \\
\hline CY 2008 & 7.0 mtons & 4.2 mtons & 11.2 mtons \\
\hline CY 2007 & 7.1 mtons & 40.9 mtons & 48.0 mtons \\
\hline CY 2006 & 11.2 mtons & 354.5 mtons & 365.7 mtons \\
\hline
\end{tabular}

${ }^{*}$ mtons $=$ metric tons

Table 3 compares solid waste generation in CY 2010 to prior years. Both routine and cleanup solid waste generation decreased from the previous year. The volume of cleanup waste generated is dependent upon the number and scope of cleanup projects funded during the year. 


\section{Table 3. Solid Waste Generated}

\begin{tabular}{|c|c|c|c|}
\hline & Routine & Cleanup & Total \\
\hline CY 2010 & $1,504.7$ mtons & $2,043.9$ mtons & $3,548.6$ mtons \\
\hline CY 2009 & $1,963.8$ mtons & $4,049.2$ mtons & $6,013.0$ mtons \\
\hline CY 2008 & $2,654.1$ mtons & $5,027.0$ mtons & $7,681.1$ mtons \\
\hline CY 2007 & $2,355.2$ mtons & $5,723.7$ mtons & $8,078.9$ mtons \\
\hline CY 2006 & $4,824.0$ mtons & $6,175.0$ mtons & $10,999.0$ mtons \\
\hline
\end{tabular}

\section{Comparison of Volume and Toxicity Reductions of Waste in CY 2010 to Prior Years}

P2 techniques and practices are implemented for all activities that may generate waste. These P2 activities result in reductions to the volume and/or toxicity of waste actually generated on site. Table 4 compares the amounts of radioactive, hazardous, and solid wastes reduced in CY 2010 to prior years.

\section{Table 4. Waste Reduced through P2 Activities}

\begin{tabular}{|c|c|c|c|}
\hline & $\begin{array}{c}\text { Radioactive Waste } \\
\text { Reduced }\end{array}$ & $\begin{array}{c}\text { Hazardous Waste } \\
\text { Reduced }\end{array}$ & $\begin{array}{c}\text { Solid Waste } \\
\text { Reduced }\end{array}$ \\
\hline CY 2010 & $0.0 \mathrm{mtons}$ & $138.8 \mathrm{mtons}$ & $648.5 \mathrm{mtons}$ \\
\hline${ }^{* *}$ CY 2009 & $45.2 \mathrm{mtons}$ & $114.0 \mathrm{mtons}$ & $624.0 \mathrm{mtons}$ \\
\hline CY 2008 & $28.9 \mathrm{~m}^{3}$ & $189.6 \mathrm{mtons}$ & $746.4 \mathrm{mtons}$ \\
\hline CY 2007 & $0.0 \mathrm{~m}^{3}$ & $53.0 \mathrm{mtons}$ & $418.0 \mathrm{mtons}$ \\
\hline CY 2006 & $0.0 \mathrm{~m}^{3}$ & $147.0 \mathrm{mtons}$ & $803.0 \mathrm{mtons}$ \\
\hline
\end{tabular}

** Beginning with CY 2009, Radioactive Waste Reduced is reported in mtons.

The following tables show an overview of the estimated volume reductions accomplished during CY 2010, through implementation of P2/waste minimization activities. Table 5 shows an estimated $138.8 \mathrm{mton}$ reduction of RCRA, TSCA, and state-regulated hazardous waste. Table 6 shows an estimated 648.5 mton reduction of sanitary waste. 


\section{Table 5. CY 2010 Hazardous Waste Reductions}

\begin{tabular}{|c|l|c|}
\hline $\begin{array}{c}\text { Waste } \\
\text { Minimization } \\
\text { Activity }\end{array}$ & \multicolumn{1}{|c|}{ Activity } & $\begin{array}{c}\text { Volume } \\
\text { Reduction } \\
\text { (mtons) }\end{array}$ \\
\hline Recycle/Reuse & $\begin{array}{l}\text { Bulk used oil and antifreeze sent to an offsite vendor for } \\
\text { recycle. }\end{array}$ & 82.3 \\
\hline Recycle/Reuse & Lead acid batteries shipped to an offsite vendor for recycle. & 29.0 \\
\hline Recycle/Reuse & $\begin{array}{l}\text { Leased computer equipment returned to the vendor for } \\
\text { refurbishing and sold for reuse. }\end{array}$ & 5.8 \\
\hline Recycle/Reuse & $\begin{array}{l}\text { Electronic equipment including computer towers, monitors, } \\
\text { laptops, and televisions, sent to an offsite vendor for } \\
\text { recycle. }\end{array}$ & 16.6 \\
\hline Recycle/Reuse & $\begin{array}{l}\text { Spent fluorescent light bulbs, mercury lamps, metal hydride } \\
\text { lamps, and sodium lamps sent to an offsite vendor for } \\
\text { recycle. }\end{array}$ & 1.0 \\
\hline Recycle/Reuse & $\begin{array}{l}\text { Rechargeable and alkaline batteries sent to an offsite vendor } \\
\text { for recycle. }\end{array}$ & 4.1 \\
\hline TOTAL & & $\mathbf{1 3 8 . 8}$ \\
\hline
\end{tabular}




\section{Table 6. CY 2010 Solid Waste Reductions}

\begin{tabular}{|l|l|c|}
\hline $\begin{array}{c}\text { Winimization } \\
\text { Type }\end{array}$ & \multicolumn{1}{|c|}{ Activity } & $\begin{array}{c}\text { Volume } \\
\text { Reduction } \\
\text { (mtons) }\end{array}$ \\
\hline Recycle/Reuse & Mixed paper and cardboard sent offsite for recycle. & 101.5 \\
\hline Recycle/Reuse & $\begin{array}{l}\text { Single stream-mixed paper/cardboard/cans/plastic sent offsite } \\
\text { for recycle. }\end{array}$ & 476.3 \\
\hline Recycle/Reuse & $\begin{array}{l}\text { Food waste from the cafeterias sent offsite for reuse as pig } \\
\text { feed for a local pig farmer. }\end{array}$ & 34.9 \\
\hline Recycle/Reuse & $\begin{array}{l}\text { Shipping materials including pallets, styrofoam, bubble wrap, } \\
\text { and shipping containers reused onsite. }\end{array}$ & 7.8 \\
\hline Recycle/Reuse & Spent toner cartridges sent offsite for recycle. & 0.7 \\
\hline Recycle/Reuse & Aluminum cans sent offsite for recycle. & 0.8 \\
\hline Recycle/Reuse & Tires sent offsite for recycle. & 26.5 \\
\hline TOTAL & & $\mathbf{6 4 8 . 5}$ \\
\hline
\end{tabular}

